\title{
Whose city is it anyway? \\ Middle class imagination and \\ urban restructuring in twenty- \\ first century Kolkata
}

\author{
Henrike Donner
}

\begin{abstract}
This article provides an overview of the way in which post-liberalization urban restructuring is determined by middle class imaginations and lifestyles in Kolkata, India. It charts how the conjunction between planning, politics and private investment made middle class hegemony in the new urban politics possible, and how the processes that have been set in motion create new spatializations according to class through exclusions and reformulate citizenship as social relationships are redefined in the language of markets.
\end{abstract}

Keywords: Middle class, urban space, India, Kolkata, neoliberalism

\section{Introduction}

Today a large number of citizens in urban India would describe themselves as being "middle class." The term is conspicuous in media representations and on the street. Everyday conversations, especially in the nation's growing urban centers draw on the category of class to describe newly upwardly mobile communities and emerging consumer cultures, and media hail the middle class as a growing mass of consumers driving economic change.

From independence up until the 1990s, the notion of a homogenous middle class referenced the families of government employees and professionals, who consciously fashioned and represented themselves in these terms, and whose hegemonic culture stemmed from their involvement with the institutions and politics of the state. ${ }^{1}$ As Jaffrelot and van

Henrike Donner, Oxford Brookes University, Department of Social Sciences, Gipsy Lane, Headington, Oxford OX3 OBP, h.donner@brookes.ac.uk.

1 See, B.B. Mishra, The Indian Middle Classes: Their Growth in Modern Times (Oxford: Oxford University 
der Veer have argued, the cult of a "self-assured bourgeois nationalism" that marked their shared middle class culture perpetuated the close association of these mostly upper-caste, salaried elites with particular lifestyles, as did their involvement with the state sector. ${ }^{2}$ Gradually, middle class self-representations became a significant objective as well as a subjective reality, which is particularly relevant in the case of Bengal, where such a self-conscious section "between the rich and the poor" began to identify itself as being in the middle in the colonial period and where such a notion became hegemonic in political discourses.

Today, the self-professed middle class(es) in India present a much more heterogeneous picture than ever before, and the notion of being middle class is no longer solely dependent on access to salaried employment. With the middle class benefitting disproportionately from economic reform and investment by the post-liberalization state, not only has the number of those economically well-off grown, liberalization is also closely associated with the rise of the middle class as a political power in India. In the process, the values of the so-called old middle class of government servants and professionals had held have come under pressure, and their way of life-the privileges that their close association with the state had accrued-is gradually disappearing. Since liberalization has kicked in, more and more communities have access to the sites and markers of middleclassness, even though they may stem from very different economic and social backgrounds and were traditionally excluded from the kind of status that this label entails.

These transformations are particularly pertinent in urban areas, where, as Fernandes has pointed out, there is nothing new about the middle class as an important player in politics, but where the so-called new middle class stake their claim to status more exclusively on economic standing, the outward sign of which is participation in the rituals of consumerism evidenced and experienced within the new spatial order of cities across India.

The genealogy of the middle class as a relevant category to describe Indian politics and the way in which the middle class figures in narratives of social change are intertwined with the discourse around economic reform. In the process, excessively economistic perspectives on this section of the population fill the media and have also informed a number of recent surveys, partly carried out for the purpose of planning and partly

Press, 1961).

2 Christophe Jaffrelot and Peter van der Veer, "Introduction," in Patterns of Middle Class Consumption in India and China, eds. Christophe Jaffrelot and Peter van der Veer (Delhi: Sage, 2008), 20. 
to chart the "markets" available for the taking in neoliberal India. ${ }^{3}$ Social scientists, on the other hand, have written excessively about the "culture" of this new middle class, utilizing semiotic and post-colonial theory to analyze the way in which the discourse about liberalization and middle class consumerism has constituted national identity in novel ways. ${ }^{4}$

The opening of the formerly protected Indian markets to foreign investment and an explicit emphasis on state disinvestment through policies characterized "liberalization," which kicked in seriously with the second wave of reforms from 1991 onwards. The outcomes of these reforms have been discussed ever since, with supporters of neoliberal economics claiming that the sustained growth of the Indian economy made India a player in a globally integrated market and has benefitted large numbers of citizens, while opponents emphasize that the reforms only benefitted the "new" middle class and have actually increased disparities and thereby created more inequality between the urban poor and the middle class, rural and urban areas, and different regions. ${ }^{5}$ Thus, whilst the selfregulatory dynamics of markets are expected to ultimately change the lives of the entire population, and there is evidence of upward mobility in certain sections, critics argue that by dismantling the public sector and encouraging markets in previously strictly regulated and often subsidized industries the state has systematically marginalized the poor, prioritized the demands of the growing number of affluent citizens, focused on the development of urban sites rather than the villages, and has underdeveloped certain state within the union.

Regardless of where one stands on the issue of foreign investment and economic liberalization, there can be no doubt that the reforms changed the life of Indian citizens and promoted new, "neoliberal" policies across India. These policies came into their own in the 1990s and have reshaped the political landscape as the ways in which the relation-

3 For an example of an empirical social science perspective, see E. Sridharan, "The Growth and Sectoral Composition of India's Middle Class: Its Impact on the Politics of Economic Liberalization," India Review 3, no. 4 (2004); for an example of corporate surveys charting the middle class in terms of economic indicators see Jonathan Ablett et al., "The 'Bird of Gold': The Rise of India's Consumer Markets," (McKinsey Global Institute, 2007).

4 See, William Mazzarella, Shoveling Smoke: Advertising and Globalization in Contemporary India (Durham: Duke University Press, 2003); Arvind Rajagopal, "Thinking About the New Middle Class: Gender, Advertising and Politics in an Age of Globalisation," in Signposts: Gender Issues in Post-Independence India, ed. Rajeswari Sunder Rajan (Delhi: Kali for Women, 1999); Rupal Oza, The Making of Neoliberal India: Nationalism, Gender, and the Paradoxes of Globalization (Delhi: Routledge, 2006).

5 See, for instance Sripad Motiram and Sarma Nayantara, "Polarization, Inequality and Growth: The Indian Experience," Ecineq (2011); and the various chapters in Anthony Heath and Roger Jeffery, eds., Diversity and Change in Modern India: Economic, Social and Political Approaches (Oxford Oxford University Press, 2010). 
ships between the governed and the government are represented and understood have been reworked.

In the propaganda that accompanied Nehruvian nationalism prevalent after independence, development through rational and secular governance combined effortlessly with redistribution, materialized in the form of a planned economy, an emphasis on economic independence, and subsidies for the "poor". Large-scale industrialization programs were initiated, and in some states, West Bengal among them, land reforms were implemented. This emphasis on the countryside and industrialization where none had existed before fed into the image of India's development based prosperity of her villages, but was in fact driven by a flourishing politics of votebanks, the most lucrative of which are even today located in rural areas. But, as Khilnani has argued among others, urban politics played an equally decisive role in Indian post-independence politics, albeit a very contested one, as the case of Kolkata demonstrates. ${ }^{6}$

Situated within the state of West Bengal, Kolkata emerged as a colonial center and enjoyed rapid growth until the 1960s. As a city, its heydays were limited-not only did the shift of the colonial administration to Delhi make it into a provincial capital, partition robbed it of its hinterland and brought millions of refugees to the now Indian part of Bengal, most of whom settled in Kolkata. For decades after independence, the city, and with it the state of West Bengal, experienced an economic downturn, and, as Chakravorty has suggested, "the liberalization process appeared to have been a heaven-sent."7 By the 1990s, when liberalization kicked in, the ruling Left Front had been neglecting the needs of urbanites in favor of their rural votebanks from 1977 onwards, and although there had been attempts to devise a master plan for "Greater Calcutta" in the 1970s, the city had not seen much in the way of urban development, regeneration, or large-scale planning apart from the so-called "metro" 8 in 1984. From the 1990s onwards, however, the city began to figure more prominently in Left Front politics, as the state government began to invest heavily in urban infrastructure, intending to garner support from a new force in post-liberalization India, the middle class consumer citizen, in order to stay in power.

6 See Khilnani's dicussion of the rural-urban divide in foundational myths of Indian politics, Sunil Khilnani, The Idea of India (Delhi: Penguin, 2003).

7 Sanjay Chakravorty, "From Colonial City to Global City? The Far-from-Complete Spatial Transformation of Calcutta," in Clobalizing Cities: A New Spatial Order?, eds. Peter Marcuse and Ronald van Kempen (Oxford: Blackwell, 1999).

8 The Indian cities Delhi, Bombay/Mumbai, Madras/Chennai, Calcutta/Kolkata and Bangalore/Bengaluru are commonly collectively referred to as "metros." This denotes a common culture relevant to the middle classes as well as shared statistical characteristics. 
Preceding this phrase, urban middle class citizens had challenged the consensus about the way in which the state defined "progress" and "development" in the post-Nehruvian era more openly, for instance in the form of Hindu nationalism, a move against state-ordered secularism, and more commonly by criticizing even moderate affirmative action. A first glimpse of this new voice in Indian politics was therefore apparent when the recommendation of the so-called Mandal commission to increase affirmative action efforts by raising the number of "reserved seats" for students from backward communities in government schools, colleges and public sector jobs, caused an uproar among middle class students. These protests indicated that by now the idea of redistribution was refuted by a significant minority of the electorate, and it was apparent that the growing urban middle class was more or less united in its hostility to the agenda of development directed towards the "upliftment" of the most marginalized sections of society.

Middle class discontent did initially rise as liberalization policies kicked in, when the upper middle class - often congruent here with the old middle class that consists of professionals and the upper echelons of government servants - saw their traditional privileges threatened by the ongoing democratization of politics, while the more numerous but lesseducated lower middle class began to fear too much competition and social and financial insecurity. ${ }^{9}$ These anxieties were particularly pronounced in West Bengal, where a virtual elite of government employees had been institutionalized by the Left Front, whose sense of deprivation related to the very real possibility of redundancies, loss of pensions and other perks and worries about the future of their children. ${ }^{10} \mathrm{But}$, on the whole, the reforms were initially supported whole-heartedly by middle class citizens across India, and as the 1990s saw the opening of India's markets to foreign investment, disinvestment in the public sector and support for business, export-oriented industries and the burgeoning ITrelated sector as well as the emergent globalized consumer culture were fully embraced.

In urban areas these policies had drastic and visible consequences, which are often glossed over in terms of "regeneration" and "urban restructuring." The narratives of the growth in power and size of the Indian middle class are closely related to these processes. In the case of

9 For an overview of Indian politics during the 1990s with special reference to the politics of backward communities and the growth of Hindu nationalism see, Stuart Corbridge and John Harriss, Re-Inventing India: Liberalization, Hindu Nationalism and Popular Democracy (Cambridge: Polity, 2000).

10 See, Ruchira Ganguly-Scrase and Timothy J. Scrase, Globalization and the Middle Classes in India: The Social and Cultural Impact of Neoliberal Reforms (London: Routledge, 2009). 
Bangalore, for example, the rise of IT-related industries transformed a former garden city into India's Silicon Valley and created a whole new and iconic middle class subculture centered around specific qualifications, workplaces, and urbanities classed as modern, rational and desirable. ${ }^{11}$ Elsewhere, for example in the southern state of Tamil Nadu, towns emerged solely on the back of specific industries - in the case of Coimbatore and Tiruppur, textiles for export-and this urbanization created a local class of newly affluent middle class entrepreneurs from specific rural caste backgrounds. ${ }^{12}$ Here, narratives of mobility and regional history have now become entwined with the new global Indian middle class lifestyle, and this has depended more and more on specifically designed urban settings.

But it was not only newly urbanized areas that felt the winds of change; soon the metros-Chennai, Delhi, Mumbai and Kolkatawere reordered and reshaped in order to cater to the needs of these lifestyles and to nurture the demands of a growing urban elite.

Thus, the growing literature on the suburbanization of Delhi charts how, combining the spin of "a global city" in the wake of the Commonwealth Games, the demands of these upwardly mobile sections of the population drove the planning and execution of urban restructuring, in an attempt to create a capital worthy of a leading nation. ${ }^{13}$ Like in all other metros, the completion of this aspiration necessitated the removal of the urban poor and their livelihoods from the streets, but in the capi-

11 See, John C. Stallmeyer, Building Bangalore: Architecture and Urban Transformation in India's Silicon Valley (London: Routledge, 2011); Carol Upadhyay, “India's 'New Middle Class' and the Globalising City: Software Professionals in Bangalore, India," in The New Middle Classes: Globalizing Lifestyles, Consumerism and Environmental Concern, eds. Hellmuth Lange and Lars Meier (Dordrecht: Springer, 2009); Nicolas Nisbett, "The Internet, Cybercafes and the New Social Spaces of Bangalorean Youth," in Locating the Field: Space, Place and Context in Anthropology, eds. Simon M. Coleman and Peter Collins (Oxford: Berg, 2006).

12 See, Sharad Chari, Fraternal Capital: Peasant-Worker, Self-Made Man and Globlization in Provincial India (Stanford: Stanford University Press, 2004); Geert de Neve, "Keeping It in the Family: Work, Education and Gender Hierarchies among Tiruppur's Capitalist Industrialists," in Being Middle Class in India: A Way of Life, ed. Henrike Donner (London: Routledge, 2011).

13 In Delhi, urban restructuring has been closely related to the legal and symbolic role of a capital and has resulted in massive slum relocations and squatter evictions which were driven by a politics of accommodation vis-à-vis an affluent urban middle class. See for instance, Amita Baviskar, "Between Violence and Desire: Space, Power and Identity in the Making of Metropolitan Delhi," International Social Science Journal 55, no. 1 (2003); "Spectacular Events, City Spaces and Citizenship: The Commonwealth Games in Delhi," in Urban Navigations: Politics, Space and the City in South Asia, eds. Jonathan Shapiro Anjaria and Colin McFarlane (Delhi: Routledge, 2010); Ursula Rao, "Making the Global City: Urban Citizenship on the Margins of Delhi," Ethnos 74, no. 4 (2010); Christiane Brosius, India's Middle Class: New Forms of Urban Leisure, Consumption and Prosperity (Delhi: Routledge, 2010); Shoma Munshi, "Yeh Dil Maange More ... : Television and Consumer Choices in a Global City," in Patterns of Middle Class Consumption in India and China, eds. Christophe Jaffrelot and Peter van der Veer (Delhi: Sage, 2008). 
tal special legislation enabled the state government (Delhi is governed independently from any of the states) to create a central area free of slums, hawkers, and informal markets. Furthermore, like in other global cities, expensive infrastructure was provided to build satellite cities, which consisted of large residential areas for middle class residents and separate business districts housing the booming enterprises that liberalization has kicked off. The development of these townships demanded the provision of roads for private transport and the relocation of "polluting" industries, communities, and activities outside the city proper, within which new legal provisions made the presence of poor residents and their trade a criminal offence.

The new spatial divisions created in India's metropolitan areas were closely related to class, as the spatial segregation worked out for Delhi indicates. However, it is equally apparent in the case of Bombay/Mumbai, where the transformation of the vast textile mill areas into up-market residential and commercial sites commenced in the 1990s and created urban spatial relations driven by middle class lifestyles and capital flows generated in the wake of liberalization. ${ }^{14}$ What is apparent here as elsewhere is that the restructuring of Indian cities into havens for property speculators and the redefinition of rights to the city were based on the decline of industries, and in its wake the marginalization of entire neighborhoods and the working-class population. What applied to Mumbai and Delhi became soon apparent in other cities as well, namely that urban politics after liberalization would be driven by the needs of a global middle class of Indian origin and that this new scenario defined citizenship to the exclusion of the urban poor, often in terms of middle class livelihoods and consumption practices through the language of "needs," "demands," and "markets."

The research on which this article is based consists of a series of extensive fieldwork stays in Calcutta/Kolkata, the earliest being a twoyear period between 1995 and 1997, the latest six weeks in December 2011/January 2012. During those research stays I initially worked with middle class residents of Taltala, a Central Calcutta neighborhood, and

14 On Mumbai, see Arjun Appadurai, "Spectral Housing and Urban Cleansing: Notes on Millennial Mumbai," Public Culture 12, no. 3 (2000) in which Appadurai discusses how the availability of cash due to changing regulations of India's financial markets in conjunction with local histories of ethnic segregation and communal violence provided the reasoning behind the imaginary restoration of Mumbai, leaving Bombay behind. Leela Fernandes highlights how the processes of disinvestment, flexibilization of capital and restructuring of the labor force have affected the emergence of a "new" middle class as a reference group for planners, investors and citizens alike. See Leela Fernandes, India's New Middle Class: Democratic Politics in an Era of Economic Reform (Minneapolis: University of Minnesota Press, 2006). 
later on with a cluster of households in a Southern neighborhood (yearlong stays in 1999-2000 and 2002-3, respectively), who all stemmed originally from East Bengal. In the course of my later research projects, the focus was not so much on a specific area, and so I interviewed and regularly met with other middle class families, more often than not visiting their homes on consecutive occasions. During the shorter periods of fieldwork, I began to document the changes that the cityscape is undergoing and took advantage of the endless opportunities to discuss these changes and their effects on the lives of my interlocutors with middle class Kolkatans. The methods employed throughout were those appropriate for an anthropological study of urban change, namely interviews and participant observation, complemented by visual and written sources related to the subject.

\section{Urban space}

When asked about the changes that urban India is undergoing, my interlocutors, who are all middle class citizens of Kolkata, would from the mid-1990s onwards point out that the new infrastructure-such as fly-overs, highways, and bridges-indexed the changing era. Today, they specify business parks, malls, multiplexes and suburban housing as indicators of these transformations. In the case of my interlocutors who stem from lower and upper middle class families in conservative, central Calcutta neighborhoods as well as more "modern" and affluent residential areas in the south of the city, urban restructuring initially indicated "progress" as intertwined with "development" through infrastructure, which was a definition very much prevalent in post-independence India up to liberalization. As Khilnani among others has shown, large building projects embodied the Nehruvian vision of Indian modernity, and thus my interlocutors imagined continuities where they soon were to find considerable ruptures. ${ }^{15}$

Initially, the materiality of the new city was based on old patterns and processes; thus, engineering feats, like the second Hooghly Bridge linking Kolkata with Howrah, its sister across the Ganges and the vast hinterland, were celebrated as signifiers of the new era, although its completion took a phenomenal three decades from laying the foundation stone in 1972. A similar nimbus was attached to fly-overs, those ghastly roads on stilts that overshadow many of the main arteries and their surroundings across the city today. These and several other large-scale infrastructure projects were still located within the parameters of urban planning,

15 Khilnani, The Idea of India. 
its execution and its objectives, that had been developed in the aftermath of independence. However, curiously, middle class residents welcomed the bridges and fly-overs as "progress," even though at the time no one could have foreseen that many of these households would actually be able to buy their own cars. Thus, it appeared that, more so than for practical reasons, fly-overs were seen as triumph of planning over politics (the anti-urban bureaucracy and the corruption associated with the Left Front by then), and that these new roads redefined spatial relationships within the city, bypassing "congested" and "problematic" areas. In a way they symbolized the speed at which the new world was materializing and where desirable middle class spaces would emerge.

In Kolkata, like in Delhi and Mumbai, the widening of roads and the presence of fly-overs invited further claims to being a "global" city, which came to be imagined in the mold of middle class citizens' ideas about American and Southeast-Asian urbanities. As described for other globalizing cities, in Kolkata, the discussion about and imagination of what a city for the twenty-first century should look like was not guided by solutions for the persisting housing crisis or inefficient educational and health provision for the masses. Although some of these issues were addressed in discussions with foreign donors, including the World Bank, throughout the 1990s and 2000s, the ruling coalition led by the Communist Party of India (Marxist) did continue to address inequality in the rural areas, while in the city it concentrated on how to kick-start economic regeneration largely in terms of roping in middle class city-dwellers. In spite of the still persisting political reasons that had made rural votebanks more attractive in the past, neoliberal policies introduced by the Central government and adopted by the states made this priority feasible. Thus, by the mid-1990s Calcutta came to be represented as an "opportunity," and the government of West Bengal reluctantly agreed to a vision that hinged on a reformed, reordered city that would deliver relief from the chronic economic stagnation of the whole state.

This reorientation was partly triggered by programs funded by the Central government and donor agencies, for instance the "Megacity Development Plan," and these programs were already designed with a view to recuperate investment in urban infrastructure. Thus, they complemented initiatives that focused on the development of a new, clean service sector, mostly IT-related industries, while existing manufacturing and trade took a back seat. ${ }^{16}$ Gradually, as neoliberal policies began to reshape the political imagination of the public-in this case, the middle

16 Chakravorty, "From Colonial City": 64. 
class readership of large newspapers - the city, or rather, urban space, came to be seen as an economic resource. ${ }^{17}$

Critical scholars of media studies have discussed how "neoliberal newspeak" developed as part of digital corporations has transformed the way in which economic facts and processes are represented across the globe. ${ }^{18}$ The new fetishization of Kolkata's cityscape was fuelled by endless articles in daily newspapers as well as the newfound voice of private TV stations that focused on the desperate state of the city's roads, on corrupt municipal officers, problems with garbage collection, and the like. Such reporting often mixed economic facts and planning with entertainment, but was framed by extensive discussions of proposed building projects, initially those by private-public partnerships, and increasingly projects supported by private investors. Among the projects hailed in the press as the advent of a new era were plans, soon to become reality, of an entirely state-funded business district set aside for IT-industries, intended to attract investors. Related were a variety of larger and smaller projects, most of which never really materialized, including waterfront regeneration and the extension of the airport, as well as extensive transport links to the suburbs and other cities in the state. What did emerge, however, were large retail and leisure complexes, and a whole set of branded schools and hospitals realized by private investors, most of which were built on plots allocated by public bodies. All these projects fed into the general, millennial sense of expectation among Kolkata's middle class citizenry, before not so much associated with a gambling culture but revelation through partaking in global consumer culture. ${ }^{19}$ Although the growing interest in urban development was partly pushed by the demands of debtors promoting neoliberal economic solutions as part of structural adjustment programs, in the process the political clout of the urban middle class did sky-rocket, because their consumption habits drive the production and representation of new urbanities in millennial capitalism and produce an economistic view of how to create a "modern" city.

17 For a corporate view on the economic viability of urban regeneration and the role of the Indian middle class, see Shirish Sankhe et al., "India's Urban Awakening: Building Inclusive Cities, Sustaining Economic Growth," (Mc Kinsey Global Institute, 2010).

18 See, Paula Chakravartty and Dan Schiller, "Neoliberal Newspeak and Digital Capitalism in Crisis," International Journal of Communication 4 (2010). This article outlines the way in which economic change is regularly presented as infotainment and I would suggest this is the chosen form of presentation of the new cityscape as well.

19 In this sense, work on the Indian middle class complements the analysis of the way in which marginalized communities are implied in millennial capitalism. See, Jean Comaroff and John L. Comaroff, "Millennial Capitalism: First Thoughts on a Second Coming," Public Culture 12, no. 2 (2000). 
In Kolkata and West Bengal as a whole, local planners and bureaucrats were implied in relation to a political landscape dominated by the hegemonic Left Front and worries about votebanks, which linked the fate of the city to the fate of its rural hinterland. ${ }^{20}$ Thus, initially the city was reinvented as a future hub for IT-related industries already dominating cities like Bangalore and Hyderabad, with which middle class Calcuttans increasingly identified their vision of the future. But soon it appeared that for the desired vision of "urban lifestyles" to be selectively promoted, Kolkata, as the city was now known, had to expand beyond its current boundaries.

The measures implemented to bring about urban regeneration in Kolkata-in this context heavily entangled with City Development Strategies (CDS) devised and promoted by various funding agenciesfocused heavily on infrastructure, clean industries, and leisure facilities (including heritage centers and amusement parks). But after the first large-scale set of projects had been implemented, planning permissions for local entrepreneurs to set up hospitals, schools, and retail facilities or to build vast residential complexes were waved through. While the first round of investment was planned and realized through the favorite vehicle of neoliberal economists, the private-public partnership, these were soon overtaken by private initiatives, most prominently engaged in real estate, retail markets and upstart businesses. Thus, what started with a substantial injection of government-initiated development has become to my interlocutors intertwined with local enterprise, as circuits of capital have become more and more about private companies siphoning off subsidies and harnessing government-funded advantages.

With a view to the urban landscape the ever-growing consumerism that has finally engulfed the city, in particular the emergence of new centers for up-market retail operations, is physically, in its materiality and in terms of its representation, seen in the same light as the increasing presence of private providers of healthcare and education. In other words, when describing and discussing urban change, my interlocutors would see shopping malls and middle class housing complexes along the same lines, as the processes that made them possible, the personnel involved and the target group were apparently the same.

The current, second phase of neoliberal urban restructuring focuses on the process of wild suburbanization, which is also found in all other Indian metros. Triggered by the promise of fast returns, investors en-

20 This link of the city with its hinterland is crucial where urban politics and economies are concerned, as Ananya Roy has shown. See, Ananya Roy, City Requiem, Calcutta: Gender and the Politics of Poverty (Minneapolis: University of Minnesota Press, 2002). 
sured the rapid construction of whole new suburbs, which are equipped with a host of facilities that cater to the lifestyles of the newly affluent segment of the middle class. Suburbs are of course not new in India, and earlier satellites like the Salt Lake township were provided by the state to mostly middle class residents. However, although the new townshipsthe most prominent one appropriately named New Town in English, but Rajarhat in Bengali-have a very different trajectory, they started out on the same premise. But driven by investments, rather than need for housing, New Town is not developed by the municipality or even the state government, but is in fact realized by a combination of bureaucrats, property speculators and (often imaginary) investors, who are publicly held responsible for the original plans. ${ }^{21}$

The global city image demanded a reordering of existing spaces as well, and thus since the 1990s a series of transformations have ensured that my middle class interlocutors see the city center in a more positive light. As pointed out above, Delhi's claim to become a restructured, truly global city rested on the eviction of slum-dwellers and squatters and the almost complete erasure of informal sector activities from the city center. This has not (yet) happened in Kolkata, a city famous for its large bustees (slums), which have co-existed with middle class housing since its inception.

However, subtle and less subtle attempts to rid the city of undesirable elements, be this residents of squatter colonies on public land, or the activities of the urban poor that sustain them and satisfy middle class demands for cheap services and goods alike, have been implemented. Firstly, "polluting industries" were charted and then made illegal and relocated-often, as in the well-documented case of the leather industry that occupied prime real estate near the city center-after long, drawnout court cases and through payment of massive amounts of publicly funded compensation. ${ }^{22}$ While their removal did diminish employment opportunities for the urban poor in the area, middle class investors and potential buyers did in turn benefit from this investment of public resources. My interlocutors, who had never been bothered by the existence of this admittedly ill-regulated and polluting industry, did however welcome the removal of the tanneries and other, smaller industries from what were potentially residential areas for "respectable people." At the

21 See, Xiangming Chen et al., "Localizing the Production of Clobal Cities: A Comparison of New Town Developments around Shanghai and Kolkata," City \& Community 8, no. 4 (2009).

22 See, Hans Dembowski, Taking the State to Court: Public Interest Litigation and the Public Sphere in Metropolitan India (Oxford: Oxford University Press, 2001). The way the public sphere is constructed in contemporary Kolkata has, however, radically changed in the meantime. 
same time their definition of what kind of economic areas should be extended to encourage "growth" resembled the classic profile of desirable middle class employment, namely white-collar office work, to be found in IT-related industries alone. ${ }^{23}$ Thus, investment in this sector facilitated two related processes that roped the middle class in as supporters of urban regeneration: firstly, it made it possible to imagine alternatives to government employment, but keep the emphasis on white-collar office work for graduates, and secondly IT-enabled industries came to symbolize the more globalized lifestyles that middle class Kolkatans associated with desirable cityscapes like Bangalore or Hyderabad.

Soon the rhetorically created and economically viable void that the absence of a comprehensive plan for economic renewal created allowed large players to monopolize the most lucrative slices of contracts, institutions, and human capital. Not all of these were multi-nationals, but my interlocutors, fed a steady diet of success stories in the media, had mostly paid attention to the presence of multi-national enterprises, such as Infosys. Soon the most respected of Indian companies and some multi-nationals had cherry-picked the real estate on offer in the newly designated "Sector V," a part of the satellite township of Salt Lake, which with its glitzy new buildings and distance from the hurly-burly of the rest of Kolkata signified a new era of urbane working arrangements. Again, the discourse of needs for the global city dominated the narrative related to these townships, which were designed for co-operations, who in turn "promised" to establish branches in the city.

In direct contrast to what working-class communities experienced here and in other Indian cities - "all that is solid melts into air" - middle class citizens were taken by the neoliberal doctrines of self-made men, of global markets, and of lifestyles promoted in relation to "merit" and scientific progress, which took on a realistic quality in these townships. It was never suggested by my interlocutors that the pact whereby local government makes the promises of corporate capital materialize would result in anything but a global city. The utopian quality of these politics were most potently symbolized by buildings-for example, those that make up the mostly new landscape of work in townships like Rajarhat, where large towers made from steel and glass are coming up and the billboards reference vast corporations with a worldwide appeal.

23 There is of course a distinction here between Bengali middle class preferences for white-collar employment opportunities and the traditional preferences among members of the business communities in the city. The latter's urban experience did not play a very prominent role in the official reimagining of the city, although they dominate the sectors that came to boom during the second phase of urban restructuring and have certainly benefitted from the new environment. 
With new sites of work in evidence, though not necessarily at the center of the local economy, the idea of the middle class as a driving force behind urban change in West Bengal has come to the fore. In the course of these developments other sites became equally significant, initially because they shared the material qualities of the shiny cooperate world. Thus, desirable hospitals and schools coming up on new plots, designated for the use of consortiums running such facilities also in other cities, resemble four-star hotels, whereas four-star hotels are designed to emulate the imagery of hyper-modernism modeled in global business districts across the world.

And finally, residential areas emerged in places where ten years ago not even roads existed, which also reflects the yearning of the middle class to tie into global Lifestyles that like those elsewhere appeal to an aspirational mode of middle class consumerism. ${ }^{24}$ Although most of the developments are rather mundane affairs, they are imagined through the outstanding publicity that flashy designer developments are given. Unlike in Delhi, most of these developments are not gated, with the really luxury ones mostly promoted to the expat (Non-Resident-Indian) category of customers. However, even apartments in the least appealing, non-gated, three-story bloc on a main road are sold along the same lines-that is, as a status symbol and investment in the future of the children, as a guarantor of "suitably modern" and middle class lifestyles. ${ }^{25}$

\section{The "new" urban middle class}

As Mazzarella has stated, the middle class has by now come to be represented mostly in terms of consumerist lifestyles, and talk about the middle class has become an "obsessive public concern." 26 However, contrary to representations of the middle class, this talk did and still does involve a profound critique of transformations that threaten institutions and relationships associated with the morality and sociality that the middle class has by and large come to associate with modernity. While the neoliberal version of this concern with the middle class associated it with

24 See, Brosius, India's Middle Class; Veronique Dupont, "The Idea of a New Chic Delhi through Publicity Hype," in The Idea of Delhi, ed. Roma Khosla (Mumbai: Marg Publications, 2005).

25 Mark Liechty has discussed the establishment of a middle class in Nepal as a "cultural project" that is based on suitably modern identities in his monograph on Nepal's capital Kathmandu. See, Mark Liechty, Suitably Modern: Making Middle-Class Culture in a New Consumer Society (Princeton: Princeton University Press, 2003)

26 See, William Mazzarella, "Indian Middle Class," in Keywords in South Asian Studies, eds. Gita Dharampal-Frick, et al. (Delhi: Oxford University Press, n.d.). Mazzarella's ethnography of advertisement professionals and the gradual shift of much advertising in cities towards the growing middle class consumer are charted in Shoveling Smoke. 
consumerism-defined in relation to markets and emphasizing the possibilities of a liberalized economy-my interlocutors were mostly wary of these easy assumptions about how their lives would be enriched and transformed. Yet, they agreed that the new era provided more and more citizens with "opportunities" and "choices," as individuals would realize their true "selves" and would be "rewarded" through increasing affluence. Whole industries, for instance the advertisement industry and Bollywood films feed into what Fernandes has called the "cultural visibility" of the middle class consumer, but this should not lead us to believe that we are dealing with a homogenous group or, for that matter, an entirely new set of values and lifestyles. ${ }^{27}$

It appears that, if we look at a specific section of the middle class in the context of regional histories and actual practices, there can be no doubt that urbanites with high disposable incomes in booming cities define themselves through participation in the neoliberal political project and cite the "market" as an indicator of progress and development. They also partake in consumer cultures that are rather homogenous and tie in with globally recognizable patterns of education, occupation and consumption. But at the same time these links and flows are determined by processes of stratification which rewrite how middle class lives are lived and how being middle class as a cultural project directed towards the reproduction of privileges is experienced. ${ }^{28}$

Unlike what we are told by the media and social scientists, public consumption practices, and histories of nationalism, whereby the "new" Indian middle class is reconstituted in the literature as a valid trope, do not fully reflect the experience of these transitions. ${ }^{29}$ The few ethnographies that cover the critical period of the 1990s, years during which structural and ideological changes altered what being middle class entailed, register the utmost resentment with which economic reform and the ideology attached to it were met. Thus, in my own research and in the work of Ganguly-Scrase and Scrase it is apparent that among the supposed winners of liberalization, namely the middle class, large sections reacted in a hostile manner to neoliberal reform, which hit those dependent on

27 See, Leela Fernandes, "The Politics of Forgetting: Class Politics, State Power and the Restructuring of Urban Space in India," Urban Studies 41, no. 12 (2004).

28 This is evident if the notion of the urban is extended beyond the metropolis and the rural elites are taken into account as well. See, Henrike Donner, ed. Being Middle Class: A Way of Life (London: Routledge, 2011).

29 See, Mazzarella, Shoveling Smoke; Arjun Appadurai and Carol A. Breckenridge, "Public Modernity in India," in Consuming Modernity: Public Culture in a South Asian World, ed. Carol A. Breckenridge (Minneapolis: University of Minnesota Press, 1995); Ritty A. Lukose, Liberalization's Children: Gender, Youth, and Consumer Citizenship in Globalizing India (Durham: Duke University, 2009). 
the massive state sector in West Bengal very hard indeed. ${ }^{30}$ Within the neoliberal rhetoric much has been made of middle class gain, even in the backwater that is Kolkata. While it would be very difficult to prove that the urban middle class constituted a conscious raison d'être initiating these processes, it became clear that urban restructuring was catering to the needs of this hegemonic group. However, certain particularities that make for a slightly different take on the relationship between the middle class and neoliberal politics need to be pointed out here.

In West Bengal, a Communist-led coalition government had been in charge until they lost the government to the populist leader Mamata Banerjee and her Trinamul Congress in 2011, and it was during the previous two decades that most of the policies considered in this article were put into place. Bengal's history is marked by the emergence of a middle class among the Bengali-speaking section of the population during the colonial period, and it is this middle class which has been dominating politics in the state since independence. During its reign, the Left Front on the one hand created a class of loyal public servants from 1977 onwards, which drew on the long-standing and self-conscious history of this "old," Bengali-speaking middle class, but largely ignored urban development and the needs and demands of urban voters in general. Thus, Left Front hegemony was built on the values and support of a certain section of the middle class, a section that subscribed to a developmentalist state, as long as the redistribution of resources did not extend to the redistribution of salaried jobs, and settled for a relatively secure but austere lifestyle.

Thus, unlike in other cities, where a "new" middle class, consisting of upwardly mobile communities and individuals capitalizing on novel opportunities, came into being, Kolkata's fate (so far) has been decided in relation to existing class relations and a model of development that favors the state as a main provider of opportunities. Furthermore, the politics of the city, which are closely intertwined with its social structure only move very gradually away from a model in which access to state resources depended on the interdependence of working-class and middle class politics. ${ }^{31}$

Partly driven by the threat of disinvestment in the state sector, which threatened middle class lifestyles and privileges as well as the survival of

30 See, Ganguly-Scrase and Scrase, Globalization and the Middle Classes; Henrike Donner, Domestic Goddesses: Maternity, Globalization and Middle-Class Identity in Contemporary India (Aldershot: Ashgate, 2008); Margit van Wessel, "Talking About Consumption: How an Indian Middle Class Dissociates from Middle-Class Life," Cultural Dynamics 16, no. 1 (2004).

31 See, Partha Chatterjee, "Are Indian Cities Becoming Bourgeois at Last?," in The Politics of the Governed: Reflections on Popular Politics in Most of the World (New York: Columbia University Press, 2004). 
the poor, and partly driven by their involvement in local politics, it took the Kolkata middle class, or more precisely its hegemonic Bengali section, a decade to join the shared vision of a post-liberalization India in which local social relations would no longer dominate everyday politics and lives. Secondly, what was felt acutely and has hampered the rapid progress of class formation along the lines of shared lifestyles and national identity is that, maybe more so in Kolkata than in other metros, the processes that might be seen as producing a new class through a shared cultural project that identifies middle class lifestyles as the defining factor are marred by inconsistencies, contradictions, and unevenness. Thus, stratification as much as collective representation and identification, and new intra-class relations are seen as defining the new era.

\section{Segregation and exclusion}

Writing about neoliberal regimes and their impact on social relations, anthropologist Aihwa Ong has suggested that neoliberal policies are constituted by a redefinition of groups "in relation to market forces" through "zoning technologies [that] have carved special spaces in order to achieve [this] strategic goal." ${ }^{2}$ In the case of urban restructuring in Kolkata, the policies that facilitated this shift consisted of the marginalization of the urban poor and the categorization of populations and places in terms of their productivity of desirable urban space. Catering to the needs of the increasingly car-owning middle class, for example, fly-overs became a potent symbol of the free flow, convenience and speed of the lifestyle envisaged and aspired to by those who have achieved. However, they do at the same time diminish road space for "undesirable" vehicles and activities now marked as encroachers (rickshaws, squatters, hawkers and the like) and link desirable spaces in the city-for example, the suburbs consisting of middle class housing and workplaces with the commercial and retail spaces of central Kolkata.

What applies to transport can also be extended to the question of housing and work in the new city: as squatters were evicted and slum settlements commodified, the government began to promote suburban developments in the form of public-private partnerships, thereby selling off land to private developers through deals that ultimately benefitted a select public.

After entire townships that were designed to attract investors and clean industries had been up for grabs, the new developments added

32 See, Aihwa Ong, Neoliberalism as Exception: Mutations in Citizenship and Sovereignity (Durham: Duke University Press, 2006), 7. 
large tracts of land to the growing portfolio of opportunities offered to the local middle class. At the same time, the opportunities available to the working poor, be that housing or livelihoods, were diminishing. The informal sector and often residing in public space were criminalized-a politics made visible for example, when hawkers were cleared from some of the main crossings in Kolkata during the infamous "Operation Sunshine" in $1996 .{ }^{33}$

As has been argued for other urban settings, for instance, the cases of Delhi or İstanbul, social segregation according to class is part and parcel of the remaking of cities into global cities. It is accomplished through the introduction of spatially segregated, often gated and surveillance-dominated residential, work and leisure environments that serve the needs of middle class citizens, and within which others - the working poor-are only allowed access for the purpose of serving these needs. ${ }^{34}$

Furthermore, this privileging of the needs and rights of middle class consumers does extend beyond the city and demand a restructuring of the relationship between the city and its hinterland. Across the state, Special Economic Zones (SEZs) that have emerged include sites as diverse as the new Kolkata township of Sector V, dedicated to clean industries, and the rural areas of Singur and Nandigram, which were intended for industrial development. ${ }^{35}$ What makes these sites exceptional is not only the fact that they are defined as quasi out of bounds for unions, but that their existence is driven by middle class desires in a new consumer-citizen-driven political economy. In the case of Sector $\mathrm{V}$, the whole township was developed to attract high-profile investors and to provide appropriate and respectable jobs for high-earning middle

33 In this event, officers of the police and representatives of the municipality forcibly evicted hawkers from major crossings. The presence of heavily unionized hawkers on the streets of Kolkata has been a political issue from the 1960 s onwards, as Bandyopadhyay's article shows, Ritajyoti Bandyopadhyay, "Hawkers' Movement in Kolkata," Economic and Political Weekly 44, no. 17 (2009). "Operation Sunshine" became infamous because it signaled the beginning of a phase during which the criminalization of poor populations began to play a significant role in local politics. The forcible removal of poor residents and communities had been almost unheard of in Calcutta since the 1970s. The hawkers resisted their resettlement in newly designed "markets" in the suburbs and subsequently reoccupied their lucrative inner-city sites. In fact, Kolkata has recently (in 2011) seen a massive increase in hawkers, allegedly because the Trinamul party, like the Left Front before it, rewarded party workers with new slots.

34 For Delhi, see Brosius, India's Middle Class; for İstanbul see Ayfer Bartu-Candan and Biray Kolluoğlu, "Emerging Spaces of Neoliberalism: A Gated Town and Public Housing Project in İstanbul," New Perspectives on Turkey, no. 39 (2008).

35 Singur and Nandigram are rural sites where compulsory purchases of land were planned in order to erect Special Economic Zones (SEZs). The struggles ensuing contributed to the downfall of the Left Front in the elections in 2011 and helped the populist leader Mamata Banerjee and her Trinamul Congress Party come to power. 
class workforces. In the case of the latter two sites, the symbolic role of the outside investors (the Indian multinational Tata and the Indonesian Salim corporation, respectively), and in the case of Singur, the product (an affordable car for the growing Indian market) were of equal importance. By reflecting global standards in overcoming local political obstacles, such as the omnipresence of unions for which West Bengal is famous, the government did in the view of my interlocutors of different political persuasions provide a new perspective for the "future" and paid tribute to the demands of the "market." 36

Furthermore, it is the massive expansion of middle class consumerism-most obviously shopping, eating out and other leisure pursuits, but also the growing market for private education and healthcarewhich has reconfigured urban politics. While the impact of such upmarket undertakings as luxury apartments and interior designers, fivestar hotels and leisure enclaves in the literature on the new middle class is vastly exaggerated, ${ }^{37}$ there can be no doubt that even my less affluent interlocutors are partaking in new consumption practices that tie in with the narrative of a global middle class lifestyle. With these new patterns, new sites for the pursuit of leisure activities, socializing, well-being and education have become part of family life and are increasingly substituting for other sites of self-fashioning; this familiarity breeds acceptance of a new politics of urban space which is often marked by dispossession and exclusion.

In Kolkata few would generally argue in favor of the permanent removal of bustees and hawkers, or for the eviction of squatters from public land. But one way the rhetoric and politics through which exclusionary politics of urban space have become acceptable is through talk about the "environment." As a range of scholars have pointed out, the discourse accompanying the newly prominent notion of the "environment" plays an important role in the neoliberal policies employed to facilitate the restructuring of urban space in India. ${ }^{38}$ Many of the dreamscapes, the aspirational spaces that have popularized middle class lifestyles much beyond the above-mentioned de facto section, are advertised as clean and green, and school children are routinely engaged in "cleaning up drives,"

36 It goes without saying that the success these initiatives had among my middle class interlocutors did not contradict their preference for a new government. None suggested that they agreed with the antiindustrialization stance of the protesters in Singur or Nandigram.

37 See for instance Brosius, India's Middle Class.

38 See, Amita Baviskar, "Cows, Cars and Cycle-Rickshaws: Bourgeois Environmentalism and the Battle for Delhi's Streets," in Elite and Everyman: The Cultural Politics of the Indian Middle Classes, eds. Amita Baviskar and Raka Ray (Delhi: Routledge, 2011); Emma Mawdsley, "India's Middle Classes and the Environment," Development and Change 35, no. 1 (2004). 
which is ironic as Kolkata must have one of the most successful guarantors of recycling in abundance, namely poor labor.

Environmental concerns reflect middle class anxieties related to urban space and class-specific ideas about public and private spaces, purity and pollution; they feed into desires for segregation, as the street represents a site of chaos, lower castes and classes and pollution, as Kaviraj has shown. ${ }^{39}$ Furthermore, they tie in with efforts of nation-building, at their lowest level drawing on older pedagogies and politics that were promoted by the state and that propagated a respect for nature, often using Hindu symbolism and terminology, in order to promote good citizenship.

These earlier systems of belief find new outlets in campaigns that unite the agencies of the state and middle class citizens, more often than not led by upper middle class spokespersons, who claim political control over urban spaces now that middle class concerns are again on the agenda, even where the poor were able to pull their weight as voters in the past. Often practical considerations, for example the flow of traffic at busy crossings, as in the above-mentioned "Operation Sunshine," drive such campaigns, which are initiated by state agencies in an attempt to make cities more manageable, but the idiom of the "environment," of "congestion" and of "pollution" mobilize on the basis of prevalent fears of contamination. Naturally, the activities and personnel removed from public space are not the middle class drivers, who clog up every available space in busy streets around shopping centers, schools and hospitals, but activities that the urban poor carry out in the "interstices" of the city. The above-mentioned examples of "Operation Sunshine," the drive to curb hawking on busy crossings, or the removal of tanneries are telling examples of this new politics of class, and so are the rules that govern access and settlement in middle class suburbs.

The discourse on the environment is only one among a set of discourses that have changed the way in which my interlocutors see the city and have modified their rhetoric in order to make the ideal of the global city their own. From what has been said so far it is apparent that processes of segregation according to class limit access to specific places in the city and that access to such spaces provides a public measure of social status and success within a great new world of opportunities. Thus, while narratives of urban transformation that put speakers in specific places are always narratives of desirable "modern" selves, especially among the young, good citizenship, which bestows rights to the city, is

39 See, Sudipta Kaviraj, "Filth and the Public Sphere: Concepts and Practices About Space in Calcutta," Public Culture 10, no. 1 (1997). 
reserved for middle class individuals. As my own research reveals, the relation of citizenship, of the very diversified usage of spaces for consumption, education, and healthcare, and the way in which the experience of these spaces - the place-making - ties in with complex and multi-faceted ideas about selves, social relations and politics, differs according to social location even within the self-confessed middle class segment of the population. ${ }^{40}$ As processes of exclusion become more permanent, for example in education or access to employment, lower middle class Kolkatans are contesting the new order and become involved in sporadic, but nevertheless persistent protests against the fragmentation of urban space and social relationships. ${ }^{41}$

Lastly, the reordering of urban space not only affects the relations between classes, but also reshapes intra-class relations. This is particularly apparent in relation to the ways in which global consumer culture is appropriated and understood - that is, the way in which the global is localized. In Kolkata, two arenas are bringing these processes of stratification and class formation out very prominently, namely healthcare and education. In both cases it is not only obvious that the new opportunities are mostly benefitting the increasingly globally connected upper middle class (professionals, top government servants, businessmen), but it is also apparent that the relationship with the state is largely mediated by the experience of access to institutions and infrastructure. Thus the cityscape and the ongoing transformation serve here as a metaphor for opportunities (markets), which are intertwined with complex ideas about "modern" selves, citizenship and social relations that my interlocutors see as facilitated by the state through the planning, execution and supervision of urban restructuring for the benefit of middle class residents.

\section{Conclusion}

As can be discerned from the above, urban India has changed dramatically in the aftermath of liberalization, and urban space has become

40 See, Henrike Donner, "Labour, Privatisation, and Class: Middle-Class Women's Experience of Changing Hospital Births in Calcutta," in Reproductive Agency and the State: Cultural Transformations in Childbearing, ed. Maya Unnithan-Kumar (Oxford: Berghahn, 2004); "Children Are Capital, Grandchildren Are Interest: Changing Educational Strategies and Kin-Relations in Calcutta Middle-Class Families," in Globalizing India: Perspectives from Below, eds. Jackie Assayag and Chris Fuller (London: Anthem Press, 2005); "New Vegetarianism: Food, Gender and Neo-Liberal Regimes in Bengali Middle-Class Families," South Asia 31, no. 1 (2008).

41 This is reflected in the increasing number of incidents where citizens take action against rogue developers and those running sub-standard services, as well as a growing number of labor disputes in sectors like banking. 
a major resource in the debates around India's integration into world markets. ${ }^{42}$ The newfound interest in Indian cities has brought a sea change in policies, with an emphasis not so much on regeneration but an entire rewriting of urban space. The accompanying processes of eviction, alienation and segregation have been charted by activists and social scientists, ${ }^{43}$ and are more often than not described as what Harvey has termed "accumulation by dispossession," ${ }^{4}$ which leaves the urban poor desperate and benefits the middle class. As I have shown, the latter play a pivotal role in these transformations not only as drivers of economic initiatives, or as benefactors of infrastructure and opportunity, but as producers of urbanities drawing on global consumer cultures and local histories. In the process, the city of Kolkata is re-imagined in terms of middle class aspirations, whereby the fiction of "progress" through urban development is superimposed on processes that have led to a fragmentation of social relationships across urban space.

While class-based debates about urban space are not new in Kolkata, and have played out on the big screen, often culminating in communal riots in the past, and more recently as a result of what Kaviraj has called the democratization of public space, ${ }^{45}$ what has changed is not only the idea of who has rights to the city, but also the kind of politics that allow different communities to realize these rights. As Chatterjee has observed, since neoliberal regimes have found their way into everyday conversations and the governance of the city, the ongoing segregation between the lives of middle class and working-class Kolkatans has changed the way in which politics works. Earlier neighborhoods were rarely homogenous and middle class residents and slum dwellers lived in close proximity, which made for a politics of cooperation and an, albeit often unequal, sharing of resources. In the past, this interdependence provided the urban poor with a voice, one mediated by "respectable" residents, whereas today, with processes of spatial segregation in evidence, the urban poor have rarely direct access to power. ${ }^{46}$

42 See, Sankhe et al., "India's Urban Awakening: Building Inclusive Cities, Sustaining Economic Growth."

43 This is reflected in the many debates around these themes that have appeared in Economic and Political Weekly over the last two decades.

44 See, David Harvey, The New Imperialism (Oxford: Oxford University Press, 2003).

45 Various authors have discussed how segregation in Calcutta did not entail the emergence of a public sphere related to urban public sites in the same way as it was the case in European cities. For a detailed analysis of the way in which class-based turned into ethnic segregation in the course of the riots before independence, see Suranajan Das, Communal Riots in Bengal, 1905-1947 (Delhi: Oxford University Press, 1993). Middle class notions of public space and post-independence approaches to public sites are discussed in Kaviraj, "Filth and the Public Sphere"; Dipesh Chakrabarty, "Open Space/ Public Space: Garbage, Modernity and India," South Asia 14, no. 1 (1994).

46 See, Chatterjee, "Indian Cities." 
It appears that the reordering of urban space in the case of post-liberalization India is very much driven by middle class desires, the realization of which involves a top-down approach, whereby a nexus of experts (planners), bureaucrats, politicians and private investors focus on projects indexing a "global city" status and where local regeneration follows suit. The reordering of urban space does not stop with the development of infrastructure and townships benefitting middle class citizens, it also manifests itself in the importance of the hinterland in the wider schemes of the neoliberal economic politics employed. As urban scholars have suggested, ${ }^{47}$ it might be now more appropriate to speak of the "metropolitan region" rather than the city, a notion that would also allow us to see some of the policies implemented in the context of the federal state (West Bengal) and transforming rural landscape. ${ }^{48}$ The new townships as well as the Special Economic Zones both challenged older notions of development and represent what Ong has called "zones of exception." 49 Not only are they exceptionally homogenous, they are financed through private developers - local, national, and international - while the acquisition and development of large tracts of land continues to be a stateregulated process, bringing in new social and economic contestations. Thus, as Chen et al. have argued, such projects draw on different kinds of planning processes and sets of assumptions than earlier developmentalist efforts and belong to the repertoire of sites that are intended to mold Kolkata into a global city. ${ }^{50}$

The image of a global city is widely influential among the middle class in Kolkata and allows for the privatization of ever larger stretches of urban space to go unchallenged. But while it is widely assumed that liberalization and urban restructuring benefitted the Indian middle class on the whole, more often than not because only economic indicators are taken as proof, neoliberal policies also challenge intra-class relations, as sections of the middle class are stripped of their privileges and lose social security. There are therefore processes of stratification at work, which bring some of the contradictions inherent in neoliberal regimes and the values promoted into the open. This is particularly pertinent in the case of Kolkata's middle class, which is not only differentiated vertically, but

47 This argument has been made by, among others, Soja and Kanai. See, Edward Soja and Miguel Kanai, "The Urbanization of the World," in The Endless City, eds. Ricky Burdett and Dejan Sudjic (London: Phaidon, 2007).

48 For an attempt to theorize the way in which rural and urban economies are intertwined and how displacement, migration and inter-class relations are constitutive of the particular urban politics of Calcutta, see Roy, City Requiem.

49 Ong, Neoliberalism as Exception.

50 See, Chen et al., "Localizing the Production of Global Cities." 
also horizontally, between different ethnic and religious groups with distinct positions in the urban spatial order and therefore variable degrees of control over the ongoing reordering of urban spatial relations.

While the ideology of self-government and individualism and the ideal of the entrepreneur are embraced in the media and in popular discourse, the notion of entitlements depends still largely on the relationship with the state in other sections.

As Chatterjee has suggested, Kolkata has finally become "bourgeois," and the middle classes have staked a new claim to the city, partly through disengaging from local politics, but at the same time reengaging with state politics. ${ }^{51}$ But unlike what Harriss has suggested for urban India in general, politics has not been left entirely to the poor; therefore, we need to establish what the new politics of the city consists of..$^{52}$ Not only does the middle class imagination constitute an active interpretation of what is happening-for example, the uproar that occurs each time politicians, developers and administrators are shown to be in cahoots with each other and a project fails, a building collapses, and so on-but as social scientists we also have to pay more attention to processes of planning, of financing and implementation, as well as transformations of the legal domain. Whole tracts of urban space-in Kolkata, for example, the former docks and the slums surrounding them-were irrelevant for middle class citizens in the past, the political imagination of the powerful middle class has been shown to actively facilitate a re-evaluation of entire sites, whereby the global lifestyle of this class is projected on supposedly unproductive urban space, which is seen as empty: an opportunity for investment.

Within this framework, citizenship and rights to the city are also linked to the individual embodiment of neoliberal values rather than solely market-driven politics, and the core institutions of middle class life, the family and gender relations are reformed accordingly. For middle class urbanites, neoliberalism as a technology of governmentality has made exclusionary practices, which are largely spatial, more important, as social relationships are subjected to an ideology of self-interest and the maximization of profits. Thus, being middle class implies that large sections of Kolkata's population identify with multiple, privileged glob-

51 See, Partha Chatterjee, The Politics of the Governed: Reflections on Popular Politics in Most of the World (New York: Columbia University Press, 2004), 142.

52 John Harriss has recently suggested that the poor are forced to resort to politics, while the middle class access resources by other means. This suggests a rather narrow view of what urban politics are about. See, John Harriss, "Antinomies of Empowerment: Observations on Civil Society, Politics and Urban Governance in India," Economic and Political Weekly 42, no. 26 (2007). 
al locations and can increasingly take part in Indian and other locales, $\underset{\mathbf{m}}{z}$ without even having to move from their Kolkata homes. The way in which the city is experienced and imagined is increasingly framed with reference to transnational and regional identities, which are laboriously constructed through everyday practices. It is in this sense that everyday practice "recast $[\mathrm{s}]$ the middle class citizen as a central agent for the revisioning of the Indian nation in the context of globalization." 53 In other words, the shared everyday reproduction of middle class cultural imaginations including the experience of urban space makes middle class lives in South Asia, and indeed beyond, comparable and the space of a globalized Indian middle class culture coherent. This coherence is probably more recent than the continuities of some themes suggest: in spite of dissent, once established, the increase in affluence in the cities and some regions in the wake of liberalization helped to bring the idea of the middle class as a driver of urban development into new terrains. Both its political imagery and its everyday practices of place-making account for entirely new spatial relations.

\section{References}

Ablett, Jonathan, Aadarsh Baijal, Eric Beinhocker, Anupam Bose, Diana Farrell, Ulrich Gersch, Ezra Greenberg, Shishir Gupta, and Sumit Gupta. "The 'Bird of Gold': The Rise of India's Consumer Markets." McKinsey Global Institute, 2007.

Appadurai, Arjun. "Spectral Housing and Urban Cleansing: Notes on Millennial Mumbai." Public Culture 12, no. 3 (2000): 627-651.

Appadurai, Arjun, and Carol A. Breckenridge. "Public Modernity in India." In Consuming Modernity: Public Culture in a South Asian World, edited by Carol A. Breckenridge. Minneapolis: University of Minnesota Press, 1995 .

Bandyopadhyay, Ritajyoti. "Hawkers' Movement in Kolkata." Economic and Political Weekly 44, no. 17 (2009): 116-119.

Bartu-Candan, Ayfer, and Biray Kolluoğlu. "Emerging Spaces of Neoliberalism: A Gated Town and Public Housing Project in İstanbul." New Perspectives on Turkey, no. 39 (2008): 5-46.

Baviskar, Amita. "Between Violence and Desire: Space, Power and Identity in the Making of Metropolitan Delhi." International Social Science Journal 55, no. 1 (2003): 89-98.

- "Cows, Cars and Cycle-Rickshaws: Bourgeois Environmentalism and the Battle for Delhi's Streets." In Elite and Everyman: The Cultural Politics of the Indian Middle Classes, edited by Amita Baviskar and Raka Ray. Delhi: Routledge, 2011.

—. "Spectacular Events, City Spaces and Citizenship: The Commonwealth Games in Delhi." In Urban Navigations: Politics, Space and the City in South Asia, edited by Jonathan Shapiro Anjaria and Colin McFarlane. Delhi: Routledge, 2010.

Brosius, Christiane. India's Middle Class: New Forms of Urban Leisure, Consumption and Prosperity. Delhi: Routledge, 2010.

Chakrabarty, Dipesh. “Open Space/Public Space: Garbage, Modernity and India." South Asia 14, no. 1 (1994): 15-31.

Chakravartty, Paula, and Dan Schiller. "Neoliberal Newspeak and Digital Capitalism in Crisis." International

53 Leela Fernandes, "Restructuring the New Middle Class in Liberalizing India," Comparative Studies of South Asia, Africa and the Middle East 20, no. 1-2 (2000): 90. 
Journal of Communication 4 (2010): 670-692.

Chakravorty, Sanjay. "From Colonial City to Global City? The Far-from-Complete Spatial Transformation of Calcutta." In Globalizing Cities: A New Spatial Order?, edited by Peter Marcuse and Ronald van Kempen. Oxford: Blackwell, 1999.

Chari, Sharad. Fraternal Capital: Peasant-Worker, Self-Made Man and Globlization in Provincial India. Stanford: Stanford University Press, 2004.

Chatterjee, Partha. "Are Indian Cities Becoming Bourgeois at Last?" In The Politics of the Governed: Reflections on Popular Politics in Most of the World. New York: Columbia University Press, 2004.

- The Politics of the Governed: Reflections on Popular Politics in Most of the World. New York: Columbia University Press, 2004.

Chen, Xiangming, Lan Wang, and Ratoola Kundu. "Localizing the Production of Global Cities: A Comparison of New Town Developments around Shanghai and Kolkata." City a Community 8, no. 4 (2009): 433-465.

Comaroff, Jean, and John L. Comaroff. "Millennial Capitalism: First Thoughts on a Second Coming." Public Culture 12, no. 2 (2000): 291-343.

Corbridge, Stuart, and John Harriss. Re-Inventing India: Liberalization, Hindu Nationalism and Popular Democracy. Cambridge: Polity, 2000.

Das, Suranajan. Communal Riots in Bengal, 1905-1947. Delhi: Oxford University Press, 1993.

Dembowski, Hans. Taking the State to Court: Public Interest Litigation and the Public Sphere in Metropolitan India. Oxford: Oxford University Press, 2001.

Donner, Henrike, ed. Being Middle Class: A Way of Life. London: Routledge, 2011.

- "Children Are Capital, Grandchildren Are Interest: Changing Educational Strategies and KinRelations in Calcutta Middle-Class Families." In Globalizing India: Perspectives from Below, edited by Jackie Assayag and Chris Fuller. London: Anthem Press, 2005.

- Domestic Goddesses: Maternity, Globalization and Middle-Class Identity in Contemporary India. Aldershot: Ashgate, 2008.

—_. "Labour, Privatisation, and Class: Middle-Class Women's Experience of Changing Hospital Births in Calcutta." In Reproductive Agency and the State: Cultural Transformations in Childbearing, edited by Maya Unnithan-Kumar. Oxford: Berghahn, 2004.

_. "New Vegetarianism: Food, Gender and Neo-Liberal Regimes in Bengali Middle-Class Families." South Asia 31, no. 1 (2008): 143-169.

Dupont, Veronique. "The Idea of a New Chic Delhi through Publicity Hype." In The Idea of Delhi, edited by Roma Khosla. Mumbai: Marg Publications, 2005.

Fernandes, Leela. India's New Middle Class: Democratic Politics in an Era of Economic Reform. Minneapolis: University of Minnesota Press, 2006.

- "The Politics of Forgetting: Class Politics, State Power and the Restructuring of Urban Space in India." Urban Studies 41, no. 12 (2004): 2415-2430.

_- "Restructuring the New Middle Class in Liberalizing India." Comparative Studies of South Asia, Africa and the Middle East 20, no. 1-2 (2000): 88-104.

Ganguly-Scrase, Ruchira, and Timothy J. Scrase. Globalization and the Middle Classes in India: The Social and Cultural Impact of Neoliberal Reforms. London: Routledge, 2009.

Harriss, John. "Antinomies of Empowerment: Observations on Civil Society, Politics and Urban Governance in India." Economic and Political Weekly 42, no. 26 (2007): 2716-2724.

Harvey, David. The New Imperialism. Oxford: Oxford University Press, 2003.

Heath, Anthony, and Roger Jeffery, eds. Diversity and Change in Modern India: Economic, Social and Political Approaches. Oxford Oxford University Press, 2010.

Jaffrelot, Christophe, and Peter van der Veer. "Introduction." In Patterns of Middle Class Consumption in India and China, edited by Christophe Jaffrelot and Peter van der Veer. Delhi: Sage, 2008.

Kaviraj, Sudipta. "Filth and the Public Sphere: Concepts and Practices About Space in Calcutta." Public Culture 10, no. 1 (1997): 83-113.

Khilnani, Sunil. The Idea of India. Delhi: Penguin, 2003.

Liechty, Mark. Suitably Modern: Making Middle-Class Culture in a New Consumer Society. Princeton: Princeton University Press, 2003.

Lukose, Ritty A. Liberalization's Children: Gender, Youth, and Consumer Citizenship in Globalizing India. Durham: Duke University, 2009. 
Mawdsley, Emma. “India's Middle Classes and the Environment.” Development and Change 35, no. 1 (2004): 79-103.

Mazzarella, William. "Indian Middle Class." In Kepwords in South Asian Studies, edited by Gita DharampalFrick, Rachel Dwyer, Monica Kirloskar-Steinbach and Jahnavi Phalkey. Delhi: Oxford University Press, n.d.

- Shoveling Smoke: Advertising and Globalization in Contemporary India. Durham: Duke University Press, 2003.

Mishra, B.B. The Indian Middle Classes: Their Growth in Modern Times. Oxford: Oxford University Press, 1961.

Motiram, Sripad, and Sarma Nayantara. "Polarization, Inequality and Growth: The Indian Experience." Ecineq (2011): 2011-2225.

Munshi, Shoma. "Yeh Dil Maange More ... : Television and Consumer Choices in a Global City." In Patterns of Middle Class Consumption in India and China, edited by Christophe Jaffrelot and Peter van der Veer. Delhi: Sage, 2008.

Neve, Geert de. "Keeping It in the Family: Work, Education and Gender Hierarchies among Tiruppur's Capitalist Industrialists." In Being Middle Class in India: A Way of Life, edited by Henrike Donner. London: Routledge, 2011.

Nisbett, Nicolas. "The Internet, Cybercafes and the New Social Spaces of Bangalorean Youth." In Locating the Field: Space, Place and Context in Anthropology, edited by Simon M. Coleman and Peter Collins. Oxford: Berg, 2006.

Ong, Aihwa. Neoliberalism as Exception: Mutations in Citizenship and Sovereignity. Durham: Duke University Press, 2006.

Oza, Rupal. The Making of Neoliberal India: Nationalism, Gender, and the Paradoxes of Globalization. Delhi: Routledge, 2006.

Rajagopal, Arvind. "Thinking About the New Middle Class: Gender, Advertising and Politics in an Age of Globalisation." In Signposts: Gender Issues in Post-Independence India, edited by Rajeswari Sunder Rajan. Delhi: Kali for Women, 1999.

Rao, Ursula. "Making the Global City: Urban Citizenship on the Margins of Delhi." Ethnos 74, no. 4 (2010): 402-424.

Roy, Ananya. City Requiem, Calcutta: Gender and the Politics of Poverty. Minneapolis: University of Minnesota Press, 2002.

Sankhe, Shirish, Ireena Vittal, Richard Dobbs, Ajit Mohan, Ankur Gulati, Jonathan Ablett, Shishir Gupta, Alex Kim, Sudipto Paul, Aditya Sanghvi, and Gurpreet Sethy. "India's Urban Awakening: Building Inclusive Cities, Sustaining Economic Growth." Mc Kinsey Global Institute, 2010.

Soja, Edward, and Miguel Kanai. "The Urbanization of the World." In The Endless City, edited by Ricky Burdett and Dejan Sudjic, 54-69. London: Phaidon, 2007.

Sridharan, E. "The Growth and Sectoral Composition of India's Middle Class: Its Impact on the Politics of Economic Liberalization." India Review 3, no. 4 (2004): 405-428.

Stallmeyer, John C. Building Bangalore: Architecture and Urban Transformation in India's Silicon Valley. London: Routledge, 2011.

Upadhyay, Carol. “India's 'New Middle Class' and the Globalising City: Software Professionals in Bangalore, India." In The New Middle Classes: Globalizing Lifestyles, Consumerism and Environmental Concern, edited by Hellmuth Lange and Lars Meier. Dordrecht: Springer, 2009.

Wessel, Margit van. "Talking About Consumption: How an Indian Middle Class Dissociates from MiddleClass Life." Cultural Dynamics 16, no. 1 (2004): 93-116. 